Joanna Górecka

Uniwersytet im. Adama Mickiewicza Instytut Filologii Romańskiej

Bernadeta Wojciechowska

Uniwersytet im. Adama Mickiewicza

Instytut Filologii Romańskiej

\title{
ROZWIJANIE ROZUMIENIA PUBLICYSTYCZNYCH AUDYCII RADIOWYCH: SPECYFIKA ETAPU POPRZEDZAJĄCEGO SŁUCHANIE
}

\section{Developing the comprehension of current affairs radio programs: working at the pre-listening stage}

The paper focuses on the development of the listening comprehension of advanced students of French as a foreign language and concerns current affairs radio programs. It presents the main conclusions discussed with reference to one of the problems researched within a larger academic project conducted from 2010 to2013. The aim of the paper is to determine some essential principles that should guide the development of questions in the pre-listening stage so that, during the subsequent while-listening stage, they could foster the individual comprehension process. The conclusions emphasize the relationship between the form and function of these pre-listening stage questions and the quality of cognitive and communicative actions performed by the listeners.

\section{Wprowadzenie}

Przegląd podejmowanych wątków badawczych dotyczących rozwijania kompetencji rozumienia ze słuchu pozwala stwierdzić dysproporcje między ilością badań dotyczących poziomów początkujących i zaawansowanych. Może wiązać się 
ona z dość powszechnym przekonaniem, że na wyższych poziomach kompetencja ta będzie rozwijać się sama, siłą własnego rozpędu i że uczeń bogaty w dotychczasowe doświadczenie będzie w stanie odtąd sam skutecznie kierować swoim rozwojem w tym zakresie. Obserwacja działań, jakie studenci studiów magisterskich filologii romańskiej podejmują w zadaniach interpretacji audycji radiowych uwidacznia jednak wiele trudności, z jakimi borykają się osoby uczące się (OU) na poziomie B2/C1. Przyzwyczajeni, na wcześniejszych etapach nauczania/uczenia się języka, do pracy z krótkimi fragmentami nagrań oraz do skupiania uwagi na warstwie informacyjnej wypowiedzi (Wilczyńska i Wojciechowska, w druku), uczniowie wydają się często bezradni w zadaniach, które wymagają formułowania i weryfikowania hipotez dotyczących warstwy implicytnej wypowiedzi czy uwzględnienia norm społeczno-kulturowych w procesie interpretacji znaczeń, a także skupienia uwagi dodatkowo na warstwie interakcyjnej. Wyzwania te wydają się rosnąć wraz z liczbą rozmówców biorących udział w danym wydarzeniu komunikacyjnym oraz długością dyskursu, chociażby ze względu na zasoby uwagi i pojemność pamięci. Problemem dla osoby uczącej się nie jest już odpowiednia segmentacja i identyfikacja jednostek leksykalno-gramatycznych oraz odtworzenie treści, ale ich interpretacja i krytyczna ocena. Reguły językowe ustępują więc normom dyskursywnym (Charaudeau 2005, Grzmil-Tylutki 2007), a kompetencja komunikacyjna wiąże się coraz ściślej z kompetencjami ogólnymi, takimi jak konstruowanie wiedzy czy krytyczne myślenie, a w przypadku audycji radiowych i programów telewizyjnych - również z kompetencjami medialnymi. Takie wielopłaszczyznowe i zintegrowane formułowanie celów rozwijania kompetencji rozumienia dyskursu na poziomie zaawansowanym jest tym istotniejsze, im bardziej osoby uczące definiują akt słuchania jako sposobność do modelowania osobistej kompetencji komunikacyjnej w oparciu o świadomy wybór wzorców działań komunikacyjnych i poznawczych (Wilczyńska 2002).

W niniejszym artykule postawiono sobie za cel lepsze uchwycenie specyfiki rozumienia na poziomie zaawansowanym w oparciu o analizę teoretyczną istniejących koncepcji kształcenia oraz sformułowanie, na podstawie wyników badania własnego, kierunków rozwijania kompetencji na etapie poprzedzającym słuchanie (fr. pré-écoute, ang. pre-listening). Zgodnie z postulatem podejścia dyskursywnego (Górecka i inni, w druku), by w procesie konstruowania i interpretowania dyskursu systematycznie uwzględniać charakterystykę gatunkową jako swoistą ramę interpretacyjną odpowiedzi, proponowane rozważania i wyniki badań odnosić się będą do wybranego gatunku, jakim jest polemiczna audycja radiowa z udziałem ekspertów i słuchaczy, a jeszcze konkretniej do audycji Le téléphone sonne nadawanej przez jedną ze stacji francuskiego radia publicznego - France Inter. Wybrane wyniki pierwszego etapu badania posłużą do określenia zasad dydaktycznych, mo- 
gących wspomóc takie konstruowanie kwestionariusza przygotowującego do zadania odsłuchu, które pozwoliłoby skutecznie wykorzystać ten etap w działaniach nauczania/uczenia się (N/U) nakierowanych na wspieranie indywidualnego procesu budowania rozumienia danej audycji radiowej.

Badanie wykorzystuje dane dwojakiej natury, tzn. opiera się na analizie odpowiedzi udzielanych przez OU oraz na analizie formy i funkcji pytań proponowanych na etapie poprzedzającym słuchanie w opracowanym przez nauczyciela (ON) kwestionariuszu. Proponowane wnioskowanie wskazuje na istnienie zależności między formą i funkcją pytań a aktywowanymi procesami poznawczymi i typem podejmowanych przez OU działań komunikacyjnych.

\section{Kompetencja rozumienia: między odtwarzaniem a interpretacją}

Analizując specyfikę zaawansowanego poziomu kompetencji komunikacyjnej nie sposób nie przywołać opisów kompetencji ESOKJ (Coste i inni, 2003). Zdefiniowane tam poziomy kompetencji rozumienia ze słuchu pozwalają uchwycić główne zakresy jej rozwoju, które można by w skrócie określić jako przejście od tekstów prostych do złożonych, od krótkich do długich, od tych zrealizowanych w języku i artykulacji standardowych do niestandardowych, od wypowiadanych w wolnym tempie do tych charakteryzujących się coraz szybszym tempem wypowiedzi, od bliskich tematycznie, codziennych do szerokich tematycznie, coraz bardziej specjalistycznych. Gdyby te formalne wyznaczniki nie zostały odniesione do gatunków, można by na podstawie takiej pobieżnej analizy wyciągnąć wniosek, że rozwój kompetencji rozumienia jest wyłącznie ilościowy (rozumieć szybciej, więcej, dłużej) i że nie ma w nim miejsca na rozwój jakościowy w sposobie interpretowania, analizowania i krytycznej oceny wypowiedzi. Rozwój jakościowy oznacza, innymi słowy, inne zarządzanie procesami uwagi, uwzględnianie i integrowanie informacji z różnych poziomów komunikacji (np. działania interakcyjne, dyskursywne, interkulturowe).

Wymiar jakościowy w ujmowaniu rozwoju kompetencji komunikacyjnej udaje się zachować dzięki odniesieniu do gatunków dyskursu (Dolz i Schneuwly 1998) a przez nie do społecznego i instytucjonalnego osadzenia wypowiedzi, do jej historii interdyskursywnej kryjącej się w warstwie implicytnej wypowiedzi oraz do pragmatycznych celów, wokół których danych gatunek się wytworzył i rozwija. Włączenie parametrów typowych dla danego gatunku w proces przygotowania do rozumienia i produkcji mowy pozwala OU na kształtowanie społecznie odpowiednich oczekiwań co do treści i przebiegu danego aktu komunikacyjnego. Odbywa się to przez sięgnięcie do zasobów wiedzy i kompetencji 
właściwych do interpretacji i oceny (wiarygodności, rzetelności, struktury, stylu, interakcji, intelektualnej czy artystycznej wartości) wypowiedzi.

Tego typu wyzwania nie mogą zostać osiągnięte w procesie dydaktycznym poprzez stosowanie zadań zorientowanych głównie na odtwarzanie warstwy informacyjnej wypowiedzi. Konieczne jest więc skorelowanie kompetencji rozumienia z kompetencją dyskursywną/generyczną (Bronckart 1996, Grzmil-Tylutki 2007, Zaśko-Zielińska 2002), a w przypadku gatunków medialnych, które są przedmiotem niniejszego artykułu, także z kompetencją medialną. Istotnym wydaje się też definiowanie zadania słuchania jako zorientowanego na realizację celów pozajęzykowych przez OU, w tym przede wszystkim na postrzeganie słuchania jako doświadczenia poznawczego opartego na działaniach myślenia krytycznego (możliwość weryfikowania swojej wiedzy, przekonań, a także uczenia się od innych, np. Coubard 2003).

Analiza poziomów kompetencji rozumienia mowy zaproponowanych przez ESOKJ (Coste i inni, 2003) pozwala stwierdzić, że do poziomu B2 rozwijanie kompetencji dotyczy głównie wypowiedzi informacyjnych i narracyjnych, często o jasnej, żeby nie powiedzieć linearnej, strukturze i kompozycji zbliżonej do języka pisanego. Kompetencja opiera się w dużej mierze na wiedzy referencyjnej i na jej wykorzystaniu w rozumieniu nowych informacji (np. w wiadomościach telewizyjnych), zaś opinie interlokutorów brane są pod uwagę tylko jeśli wyrażone są eksplicytnie.

Na poziomie C1 rozszerzona gama gatunków obejmuje również gatunki medialne zbudowane wg różnych schematów interakcyjnych, dotyczących szerokiej gamy tematycznej, często wykraczającej poza doświadczenie uczących się i o różnej długości. Pojawiają się też wymagania dotyczące rozumienia warstwy implicytnej wypowiedzi i zachodzących między interlokutorami relacji, co często jest kluczowe dla właściwej interpretacji rozmowy i co pozostaje w związku z kompetencją medialną (rozumienie jak media oddziałują na odbiorców).

Opisy sugerują, że OU na poziomie $\mathrm{C} 1$ powinna rozumieć również dyskusje i debaty z udziałem wielu interlokutorów, niezależnie od ich długości. Takie rozumienie zakłada dużą sprawność nie tylko językową, ale również kognitywną (zarządzanie pamięcią) i intelektualną, tym większą, im dłuższe są wypowiedzi (przetwarzanie, a nie tylko rejestrowanie danych, docieranie do założeń formułowanych twierdzeń), oraz medialną (np. relacje między dziennikarzem i zaproszonymi gośćmi, dobór gości i tematów, zarządzanie głosem, sposób zadawania pytań i ich zakres).

Choć ESOKJ (Coste i inni, 2003) wskazuje na gatunki, jest to wskazanie natury bardzo ogólnej i nie daje rozeznania, co do zależności między parametrami jakościowymi i ilościowymi wypowiedzi, ani tym bardziej nie określa sposobów rozwijania kompetencji rozumienia mowy na poziomach B2 i wyż- 
szych w oparciu o podejście gatunkowe. Nadmienić niemniej należy, że powyższe ograniczenia są zrozumiałe, zważywszy na charakter i cel tej publikacji.

\section{Specyfika przedstawianego projektu na tle istniejących badań}

W świetle ustaleń wstępnych dotyczących modelowania kompetencji słuchania w ESOKJ (Coste i inni, 2003), celowe wydaje się wypracowanie koncepcji rozwijania sprawności słuchania dostosowanej do specyfiki kształcenia na poziomie zaawansowanym (B2/C1) oraz uwzględniającej potrzeby i możliwości uczących się w środowisku filologicznym. Omówienie założeń proponowanego podejścia dyskursywnego poprzedzone zostanie krótkim przeglądem dominujących tendencji w glottodydaktycznych badaniach nad sprawnością słuchania. Osadzenie specyfiki projektu na tle istniejących badań pozwoli następnie lepiej uzasadnić potencjał proponowanego w badaniu ujęcia, integrującego, w ramach sprawności słuchania, kompetencje generyczną, interkulturową oraz medialną.

\subsection{Obraz kompetencji rozumienia ze słuchu w badaniach glottodydaktycznych}

Jak już wcześniej zasygnalizowano, zauważyć można niedobór badań zmierzających do lepszego zrozumienia procesów rozwijania kompetencji rozumienia na poziomie zaawansowanym, tj. nie tyle zorientowanych na wąsko definiowaną specjalizację zawodową, np. tłumaczenie (por. Leaver i Shekhtman 2002), ile zmierzających do określenia warunków doskonalenia sprawności słuchania w zakresie doświadczeń codziennych, na przykład odbioru audycji radiowych i telewizyjnych. Tymczasem, przedstawiany projekt opiera się na założeniu, że rozumienie dokumentów medialnych stanowi jedną z podstawowych umiejętności w języku obcym i że świadome kształcenie kompetencji słuchania, połączone z rozwijaniem kompetencji medialnej oraz generycznej, powinno podlegać uporządkowanym działaniom dydaktycznym, tj. uwzględniać progresję w formułowaniu celów słuchania oraz w doborze trenowanych strategii słuchania.

W proponowanej tu koncepcji definiuje się procesy rozumienia jako strategiczne i wpisuje się tym samym w perspektywę podzielaną przez wielu badaczy. Jednocześnie jednak, pomimo że badania nad rozumieniem bardzo często skupiają się na zadaniach weryfikujących umiejętność słuchania rozumianą jako działanie strategiczne (Berne 2006), zauważyć można, że uwzględniane strategie dotyczą przede wszystkim procesów zapamiętywania, selekcji i odtwarzania wybranych informacji. I tak, wiele uwagi w bada- 
niach poświęca się strategiom kognitywnym (Poussard 2003) oraz metakognitywnym (Vandergrift i inni, 2006, Vandergrift i Tafaghodtari 2010). Dominujące podejście ujmuje więc proces rozumienia w kategoriach odsyłających do ogólnych wyznaczników sytuacji komunikacyjnej (miejsca, treści i interlokutorów), a niewiele jest badań, których autorzy akcentowaliby specyfikę gatunkową dokumentu medialnego (Kamber i Skupień 2009). Podobnie, zadania testowe rzadko tworzone są w oparciu o programy medialne $z$ udziałem kilku rozmówców i/lub z dłuższymi sekwencjami monologowymi.

Sygnalizowane wyżej dominujące reprezentacje zadania słuchania jako zorientowanego na odtwarzanie danych i informacji nie pozostaje bez konsekwencji dla wyobrażeń samych uczących się. Jak zauważa F. Coubard (2003), uczniowie bardzo często traktują odsłuch jako sprawdzian znajomości słownictwa i struktur oraz sposób na ich wzbogacenie, a nie jako okazję do rozwijania wiedzy społeczno-kulturowej czy jako sposobność rozwijania strategii słuchania i-jednocześnie - rozumienia. ${ }^{1}$

Można niemniej przypuszczać, że coraz większa powszechność nowych technologii komunikacyjnych i regularne doświadczenia z mediami elektronicznymi niewątpliwie wpłyną na wzrost liczby badań zorientowanych na rozwijanie umiejętności słuchania poprzez zadania akcentujące wymiar poznawczy i dyskursywny dokumentów (por. Strzemeski 2011).

\subsection{Model rozwijania sprawności rozumienia w ujęciu dyskursywnym}

Przyjęta tu koncepcja określona jest jako tzw. zintegrowany model rozwijania kompetencji rozumienia, w którym rozwijanie sprawności rozumienia zasadza się na integrowaniu umiejętności językowo-komunikacyjnych, informatycznych oraz wiedzy na kilku płaszczyznach:

- kompetencji komunikacyjnych i kognitywnych (w tym kompetencji kulturowej),

- kontekstu języka ojczystego i języka obcego (lub kilku języków obcych),

- kompetencji medialnej i kompetencji związanych z korzystaniem z nowych technologii (kompetencji informacyjnych i informatycznych),

- rozwijania autonomii w korzystaniu z obcojęzycznych dokumentów medialnych, w tym zwłaszcza krytycznej ich oceny.

\footnotetext{
${ }^{1}$ Należy przy tym podkreślić, że współczesne materiały dydaktyczne coraz częściej odwołują się do bardziej złożonej definicji kompetencji rozumienia, a co za tym idzie uwzględniają wymiar dyskursywny w zadaniach słuchania. Przykładem takiej praktyki jest podręcznik Grandet i inni, 2007. „Activités pour le Cadre Européen Commun de Référence. Niveau B2" (CLE International).
} 
Koncepcja ta rozwijana jest od roku 2010 przez pracowników Zakładu Dydaktyki Języków Romańskich w Instytucie Filologii Romańskiej UAM, a jej omówienie było przedmiotem kilku publikacji (Górecka i inni, w druku; Wilczyńska i Wojciechowska, w druku). Poniżej przywołane zostaną te zakresy ujmowania kompetencji rozumienia, które decydują o specyfice rozumienia publicystycznych gatunków radiowych i które stanowią teoretyczną ramę badania.

\section{Definiowanie kompetencji słuchania w odniesieniu do publicystycznych gatunków radiowych}

W centrum proponowanego modelu znalazło się określenie specyfiki tzw. kompetentnego słuchacza (por. Wilczyńska i Wojciechowska, w druku), tj. słuchacza, który nie tylko potrafi zrozumieć treść wypowiedzi w języku obcym, ale także ocenić jej skuteczność w odniesieniu do realizowanych przez rozmówców intencji komunikacyjnych, a także dostrzec i wykorzystać w procesie budowania znaczeń zależność między formułowaną argumentacją a rolą społeczną rozmówców. Postulowane umiejętności słuchania wykraczają więc poza kompetencje językowe i sytuują się $w$ dużej mierze na poziomie działań dyskursywnych. Oznacza to, dla słuchającego, konieczność osadzania interpretacji wypowiedzi w specyfice konwencji dyskursywnej właściwej dla danego gatunku medialnego. Zadanie dydaktyczne winno więc rozwijać umiejętność formułowania oczekiwań wobec przebiegu interakcji, poruszanych tematów oraz prezentowanych ujęć. Powinno także zwracać uwagę na kryteria doboru zaproszonych rozmówców i wynikających $z$ ich obecności w audycji form problematyzowania oraz form i jakości współtworzonych ustaleń i wniosków.

Wynika z powyższego, że umiejętności słuchania powinny być definiowane $w$ odniesieniu do konkretnego gatunku medialnego, a ich rozwijanie powinno wiązać się, z jednej strony, z uwrażliwianiem OU na stałe właściwości danej audycji (np. czas jej trwania i struktura) a - z drugiej strony - także na te cechy, które decydują o specyfice każdego odcinka. ${ }^{2}$ Uwzględnienie cech formalnych audycji oraz elementów specyficznych dla konkretnej jego aktualizacji w poszczególnych programach jest niezbędne w budowaniu osobistej kompetencji słuchania. Dzięki osadzeniu aktu słuchania w perspektywie dyskursywnej bardziej owocne staje się podejmowanie działań aktywne-

\footnotetext{
2 Oryginalność każdej audycji uwarunkowana jest doborem zaproszonych gości, tematem rozmowy oraz poruszanymi w niej zakresami, doświadczeniem komunikacyjnym i medialnym rozmówców, ich wzajemnymi relacjami, przynależnością do określonych grup społecznych i zawodowych, itp.
} 
go słuchania i konstruowania wiedzy, w tym także działań poznawczych wyższego rzędu, takich jak myślenie krytyczne.

W ujęciu dyskursywnym podkreśla się dynamiczny, niekoniecznie linearny charakter budowania rozumienia: znaczenia negocjowane wstępnie w ramach par przyległych, niejednokrotnie podlegają dalszej negocjacji w późniejszych sekwencjach interakcji, inicjowanych przez kolejnych rozmówców.

Akcentowanie znaczenia aktywnej postawy w procesie budowania rozumienia wiąże się także z koniecznością uwrażliwiania na rolę tzw. wiedzy implicytnej w procesach konstruowania znaczeń przez rozmówców. Pojęcie to odnosi się do wiedzy, częściowo i/lub w określonych zakresach współdzielonej przez członków danej wspólnoty dyskursywnej, która nie jest bezpośrednio werbalizowana $w$ ich interakcjach, lecz która stanowi odniesienie i osadzenie dla konstruowanych przez rozmówców treści. Stąd istotnego znaczenia w procesach N/U zorientowanych na doskonalenie sprawności rozumienia dyskursu medialnego nabiera forma zadań. Otóż, konstrukcja zadania powinna prowadzić do sprawnej identyfikacji i interpretacji reprezentacji społeczno-kulturowych uznanych za podzielane przez odbiorców danego programu radiowego i osadzonych w realiach danego społeczeństwa. Pociąga to za sobą konieczność rozwijania u OU umiejętności określania potrzeby informacyjnej oraz odpowiedniego uzupełniania dostrzeżonych braków podczas konsultowania medialnych źródeł informacji, a to z kolei wiąże się ściśle z kompetencją informacyjną i interkulturową.

Podsumowując, można przypuszczać, że włączenie do modelu kompetencji rozumienia dokumentów medialnych na poziomie B2/C1 elementów analizy gatunkowej oraz medialnej będzie wspierać rozwijanie samodzielności komunikacyjnej i uczeniowej uczących się.

\subsection{Cechy gatunkowe i dyskursywne audycji Le téléphone sonne jako punkt wyjścia dla określania celów słuchania i sposobów interpretowania}

Zgodnie z przyjętym tu podejściem dyskursywnym praca nad rozumieniem audycji medialnych wiąże się z koniecznością ustalenia charakterystyki gatunkowej wybranych audycji, gdyż to właśnie ona stanowi swoistą ramę interpretacyjną, w obrębie której dokonuje się społeczna komunikacja i może stanowić cenną pomoc w procesie konstruowania znaczeń. Audycja została szczegółowo zanalizowana we wcześniejszych publikacjach (Wilczyńska i Wojciechowska, w druku), tutaj dla jasności wywodu przywołane zostaną jedynie w sposób skrótowy najważniejsze jej cechy.

Le téléphone sonne jest audycją cykliczną, nadawaną kilka razy w tygodniu od wielu już lat przez stację radiową France Inter w godzinach wieczornych, 
trwającą ok. 45 min. Proponowana problematyka jest naświetlana przez kilku (najczęściej 3-4) zaproszonych ekspertów, przedstawicieli różnych instytucji społecznych, politycznych, badawczych, akademickich, obecnych w studio lub wypowiadający się telefonicznie. Posiadają oni zwykle dobrą orientację w danej, złożonej kwestii, a ponadto prezentują sporą różnorodność punktów widzenia. W audycji biorą również udział słuchacze dzwoniący do radia lub wypowiadający się drogą mailową, ich wkład stanowi cenne uzupełnienie problematyki o konkretne, „życiowe” obserwacje i przeżycia, osadzone w osobistym doświadczeniu.

Audycja ma charakter autorski. Prowadzi ją dziennikarz, który udziela głosu ekspertom i słuchaczom oraz dba o odpowiednie pogłębianie i/lub poszerzanie poszczególnych wątków i aspektów rozważanej kwestii. Celem audycji nie jest sformułowanie ostatecznych rozwiązań czy wyprowadzenie jednoznacznych wniosków, lecz rozważanie danego problemu z różnych punktów widzenia, ukazanie jego złożoności i wielowymiarowości. W tym sensie charakter Le téléphone sonne można ogólnie określić jako opiniotwórczy.

Atrakcyjność poznawcza omawianej audycji, a także staranny, poprawny, a przy tym żywy język wypowiedzi, zadecydowały o uznaniu tego materiału jako przydatnego i cennego $\mathrm{w}$ doskonaleniu się $\mathrm{w}$ kompetencjach rozumienia ze słuchu na poziomie zaawansowanym.

Formuła audycji, a w szczególności tożsamość zaproszonych gości, dynamiczny i argumentacyjny charakter dyskusji podobnie jak jej ładunek intelektualny, przy jednoczesnym silnym uwarunkowaniu społecznym i kulturowym tych zakresów mają istotne znaczenia dla doboru skutecznych strategii słuchania. W świetle powyższej charakterystyki widać wyraźnie, że rozumienie tego typu audycji nie może sprowadzać się do odtworzenia, choćby i najwierniejszego, treści poszczególnych wypowiedzi. Kompetentny odbiór będzie wymagał podążania za złożoną interakcją krytycznej oceny wartości uzasadnień i argumentów przywoływanych przez dyskutantów. To z kolei jest możliwe z jednej strony przez odnoszenie treści dyskusji do statusu i roli społecznej dyskutantów, ich ideologicznej orientacji, a z drugiej do ich biegłości i zręczności dyskursywnej, w tym także w zakresie operowania głosem (intonacja, akcent logiczny, pewność siebie, rzutkość itp.). Aktywność osoby słuchającej powinna również skupiać się na powiązaniu danych wypowiedzi z kontekstem interdyskursywnym, które może nie być czytelny dla studentów jako osób spoza kręgu docelowych odbiorców audycji.

\section{Opis badania: wyzwania dydaktyczne dla ON}

Weryfikacja zasadności postulowanego modelu rozumienia sprawności słuchania na poziomie B2/C1, a także krytyczna ocena rozwiązań dydaktycznych 
wypracowanych na jego podstawie były przedmiotem badania przeprowadzonego w roku akademickim 2011/2012 (semestr letni i zimowy) w grupie 20 studentów I roku SUM na kierunku filologia romańska. Badanie prowadzone było metodą badania w działaniu (ang. action-research), przez dwóch współpracujących nauczycieli-badaczy, autorów niniejszego artykułu, z których każdy prowadził zajęcia dydaktyczne z grupą studentów przez jeden semestr.

W ciągu roku studenci wysłuchali, w ramach pracy własnej, 7 audycji „Le téléphone sonne", trwających każda od 35 do 45 minut. Forma podcastu umożliwiała wielokrotne odsłuchanie całej audycji lub jej fragmentów, jeśli dany student uznał takie działanie za stosowne. Zadaniem studentów było wypełnienie każdorazowo kwestionariusza przygotowanego przez nauczyciela. Na pracę własną nad jedną audycją i towarzyszącym jej kwestionariuszem studenci mieli od 2 do 3 tygodni. Kwestionariusze proponowane przez nauczycieli zawierały ok. 13 pytań każdy. Pytania te dotyczyły trzech etapów zadania słuchania:

- 3-4 pytania na etapie przed słuchaniem: ich celem było wprowadzenie $w$ problematykę poruszaną $w$ audycji. Zachęcały one nie tylko do sformułowania hipotez dotyczących treści, ale również do uporządkowania i do uzupełnienia już posiadanej wiedzy,

- 5-6 pytań na etapie słuchania. Pytania zmierzały do weryfikacji rozumienia, czyli, z jednej strony, do odtworzenia treści audycji, z drugiej zaś do jej interpretacji i oceny,

- 2-3 pytania na etapie po słuchaniu, zorientowane na ocenę doboru i jakości przedstawianych treści oraz sposobu ich współkonstruowania w interakcji przez rozmówców. Pytania zachęcały do postrzegania zadania jako doświadczenia umożliwiającego nabywanie wiedzy społeczno-kulturowej oraz ukierunkowane były na rozwijanie osobistej kompetencji komunikacyjnej w oparciu o świadomą ocenę przebiegu interakcji mających miejsce podczas trwania audycji.

Wypełnione kwestionariusze były - w ciągu kolejnych dwóch tygodni - oceniane przez nauczyciela i omawiane na zajęciach.

\subsection{Cele badania i metoda analizy kwestionariuszy}

W ramach niniejszego artykuły przedstawiony zostanie jedynie fragment badania, odnoszący się do następującego pytania: w jakim stopniu koncepcja kwestionariusza umożliwiła kierowanie aktywnością OU w zadaniach rozumienia ze słuchu zgodnie z formułowanymi celami N/U (patrz pkt. 3) w fazie poprzedzającej odsłuch? Chodzi o zrozumienie, jak „sprawdzają się” pytania nauczyciela w konkretnej sytuacji dla konkretnej grupy uczniów, jak są przez nich postrzegane i jaką rzeczywiście pełnią funkcję w przygotowaniu do efek- 
tywnego słuchania. Założono, że sposób odpowiadania na zadane w kwestionariuszu pytania pozwoli na określenie choćby przybliżone wyjściowej kompetencji OU, a tym samym na uchwycenie głównych czynników hamujących procesy budowania rozumienia.

Przeprowadzona analiza ma charakter jakościowy. Przedstawienie wyników, ich interpretacja oraz formułowane na jej podstawie wnioski zostaną uporządkowane względem dwóch osi analizy, obejmujących:

a) działania podejmowane przez OU i pozwalające wnioskować o ich umiejętnościach wyjściowych (różnice w reprezentacjach i oczekiwaniach ON i OU), analizowane na podstawie udzielanych w kwestionariuszu odpowiedzi,

b) wyzwania związane $z$ tworzeniem kwestionariusza (dostosowanie działań ON do możliwości i potrzeb OU), formułowane na podstawie obserwacji zależności między formą odpowiedzi a formą pytania.

\section{Rozwijanie kompetencji rozumienia na etapie przed słuchaniem - raport z badań}

Jedną z podstawowych i często przywoływanych funkcji etapu przed słuchaniem jest aktywizacja wiedzy oraz doświadczeń ucznia. Pytania nawiązujące do problematyki poruszanej w nagraniu mają wspomóc proces antycypacji znaczenia, a konkretnie formułowanie hipotez dotyczących treści. Wartości takiego działania należy upatrywać w teoriach poznawczych (kognitywizm i konstruktywizm), które wskazują na zasoby umysłu osoby jako na punkt odniesienia w procesie rozumienia przez nią świata i budowania nowej wiedzy. Pobudzenie odpowiednich struktur w umyśle ma na celu usprawnienie procesów uwagi i pamięci i w ten sposób zwiększenie skuteczności i ekonomii procesu rozumienia. Zważywszy jednak na fakt, że już sama wielość uczestników sugeruje różne możliwe ujęcia problematyki, refleksja dotycząca zagadnień poruszonych w audycji nie może ograniczać się do spontanicznego przywołania "stanu wiedzy", ale powinna umożliwić uświadomienie luk w wiedzy i prowadzić do uzupełniania informacji. Jest to tym istotniejsze, że podnoszone w audycji kwestie dotyczą francuskiego kontekstu społeczno-kulturowego i dlatego rozumieniu powinna towarzyszyć świadomość, w jakim polu ideologicznym sytuuje się dana wypowiedź rozmówcy czy też, szerzej, jego pozycja argumentacyjna, jaka jest jej natura i na ile jest ona wsparta rzetelnymi faktami czy argumentami, oraz jakie są inne możliwe konkurencyjne stanowiska.

Kolejną kategorią pytań, które tradycyjnie stawia się na etapie przed słuchaniem są pytania o rozmówców tworzących daną sytuację komunika- 
cyjną, czyli o osoby, które OU spodziewa się usłyszeć w nagraniu. Wbrew pozorom nie jest to pytanie banalne: określenie, choćby przybliżone, tożsamości rozmówców odzwierciedla w pewnym stopniu wyobrażenia OU co do spodziewanego kierunku rozmowy i zakresu (w warstwie tematycznej) dyskusji, możliwych miejsc kontrowersji czy wreszcie stylu wypowiedzi. Te wstępne ustalenia mogą mieć spore znaczenie dla późniejszej (na etapie słuchania lub po słuchaniu) oceny reprezentatywności dopuszczonych do głosu ekspertów czy konfrontacji formy i treści przekazu oraz określenie ich wpływu na atrakcyjność poszczególnych rozmówców. Sprawne i precyzyjne odpowiedzi na tego typu pytania świadczą z pewnością o rozwiniętej kompetencji medialnej oraz o kompetencji interkulturowej.

W omawianym projekcie, wzorowanie się przy układaniu kwestionariusza na klasycznych pytaniach proponowanych na etapie poprzedzającym słuchanie (antycypacja wiedzy oraz formułowanie oczekiwań wobec formy i przebiegu dyskusji) skutkowało odpowiedziami, które można śmiało scharakteryzować jako niezadowalające $w$ perspektywie rozwijania kompetencji komunikacyjnej na poziomie B2/C1. Oprócz określenia głównych źródeł trudności w podjęciu działań antycypacji i interpretacji na etapie poprzedzającym słuchanie (punkt 6.1.), badanie pozwoliło także uchwycić, na poziomie redakcji pytań kwestionariusza, główne słabości proponowanej techniki pracy nad rozumieniem wybranej audycji radiowej (punkt 6.3.).

\subsection{Sposób wypełniania kwestionariusza jako przejaw kompetencji rozu- mienia OU}

Przyjrzyjmy się kilku przykładom zadanych w kwestionariuszu pytań i udzielonych nań odpowiedzi.

\subsubsection{Pytania zorientowane na aktywizowanie wiedzy studentów}

Pytania mające na celu aktywizowanie wiedzy OU na etapie przed słuchaniem uchodzą powszechnie za skuteczną strategię komunikacyjną wprowadzania OU w temat. Aby ocenić rzeczywistą skuteczność tej strategii pobudzania zaangażowania OU w odniesieniu do wybranego tu publicystycznego gatunku medialnego, przeanalizowano odpowiedzi studentów, zwracając szczególną uwagę na te elementy w konstrukcji pytania, które mogą prowadzić do podjęcia przez OU działań komunikacyjnych wpisujących się w tzw. dyskurs szkolny, pozorowany. Działania takie, w świetle założeń projektu, uznano za niepożądane. 


\section{Przykład nr 1}

Pytanie: Czy Francuzi bardziej ufają mediom niż Polacy ? (z kwestionariusza do audycji Presse, télévision, radio, Internet: les Français font-ils confiance aux médias? 08.02.2011)

Odpowiedź: Uważam, że zaufanie do mediów Francuzów nie jest na tym samym poziomie co Polaków. W Polsce wierzy się jeszcze, że media przekazuja rzetelne informacje i że dziennikarze sq niezależni. Słyszy się tylko czasami jakieś podejrzenia, że media kłamiq, ale nie ma badań, które potwierdziłyby te przesqady. Tymczasem Francuzi, tak jak już to wspomniałam, nie majq zaufania do mediów, ponieważ wg nich nie sq one rzetelne $i$ wiarygodne.

Powyższy przykład z kwestionariusza do audycji podejmującej temat zaufania do mediów ilustruje często obserwowany w korpusie problem ogólnikowości udzielanych odpowiedzi, na który nakłada się jeszcze brak rzetelności w przedstawianiu informacji. Pytanie zostało zinterpretowane jako pytanie o opinię własną OU. Wyrażona opinia nie została jednakże poparta żadnymi konkretnymi danymi, OU nie uzasadnia także własnego stanowiska. Brak dostatecznej mobilizacji wiedzy wiąże się więc tutaj z brakiem podjęcia działań zmierzających do krytycznej weryfikacji prezentowanej opinii i do weryfikacji spójności stanowiska.

\subsubsection{Pytania zorientowane na krytyczną refleksję nad własnymi postawami i opiniami}

W odróżnieniu od pytań z poprzedniej kategorii, nastawionych na przywoływanie zobiektywizowanej wiedzy, oczekiwano, odnośnie odpowiedzi na pytania z poniższej grupy, umiejętności krytycznego myślenia i uzasadniania własnych przekonań i opinii.

\section{Przykład nr 2}

Pytanie: Jakie media cieszą się Twoim największym zaufaniem: radio, telewizja, prasa? Wyjaśnij dlaczego (kwestionariusz do audycji Presse, télévision, radio, Internet: les Français font-ils confiance aux médias? 08.02.2011).

Odpowiedź: Najbardziej wiarygodne sq dla mnie wiadomości telewizyjne. Myślę, że telewizja w ogóle podaje informacje sprawdzone i wiarygodne. Kiedy coś ważnego dzieje się na świecie, dowiaduję się o tym z telewizji, bo jest to dla mnie pierwsze źródło informacji.

W przykładzie tym widać wyraźnie trudności OU w uzasadnieniu opinii dotyczących własnej preferencji. Telewizja jest tu uznana za wiarygodną w całej swej rozciągłości i różnorodności - różne stacje, różne programy, różni dziennikarze. Argumenty mające wzmocnić opinię OU zostają zastąpione kolejnymi opiniami oraz narracyjnym opisem zwyczajowego działania, przyczyniając się tym samym 
do obnażenia naiwności wyrażonych przekonań. Brak tu jakiekolwiek krytycznej refleksji nad funkcjonowaniem mediów, brak wskazania na specyfikę formy podawczej i na jej konsekwencje dla konstruowania i odbioru informacji. Nic dziwnego, że studentka na dalszych etapach pracy z nagraniem ogranicza się do odtwarzania treści, nie przechodząc do etapu oceny ich jakości.

\subsubsection{Pytania zorientowane na rozwijanie kompetencji medialnej}

Celem pytań w tej kategorii było uwrażliwienie na specyfikę gatunkową publicystycznych audycji radiowych również w warstwie interkulturowej (sposób ujmowania i problematyzowania tematu w obu kulturach). Udzielone odpowiedzi ujawniają brak odwołań do aktualnie toczącej się debaty społecznej w obu kulturach (np. studenci nie odwołują się w odpowiedziach do aktualnych tekstów medialnych).

\section{Przykład nr 3}

Pytanie: Kogo spodziewasz się usłyszeć w dyskusji na ten temat? (kwestionariusz do audycji Salaires, responsabilités professionnelles: où en est-on de l'égalité hommesfemmes? 08.03.2011)

Odpowiedź: Spodziewam się usłyszeć przede wszystkim kobiety, które zostały osobiście dotknięte problemem dyskryminacji w pracy, ale także specjalistów, którzy zajmujq się problemem nierówności zawodowej i moga przedstawić konkretne liczby.

Odpowiedź studentki zawiera pewne ciekawe elementy, przede wszystkim pozytywnie należy ocenić konfrontację obiektywnych analiz specjalistów z wypowiedziami osób, których omawiany problem dotknął osobiście. Problematyczna jest natomiast tożsamość owych specjalistów, a także zbyt ogólna sugestia co do znaczenia danych liczbowych dla rozumienia poruszanej w audycji problematyki. Taka odpowiedź, choć daje pewne narzędzia obserwacji doboru rozmówców, nie w pełni pozwala na wskazanie zależności między tym doborem a kierunkiem prowadzonej rozmowy. Należy zaznaczyć, że tego typu niepełne odpowiedzi były bardzo częste, często też proponowany zestaw dyskutantów raził swoją przypadkowością i brakiem uzasadnienia. Typową cechą uzyskanych odpowiedzi był także brak różnicowania między sposobem, w jaki dany temat przedstawiany jest i omawiany w obu kulturach (polskiej i francuskiej), co niewątpliwie ma swoje przełożenie na dobór osób, odbieranych jako specjalistów w obu kontekstach.

\subsection{Podsumowanie analizy udzielanych w kwestionariuszu odpowiedzi}

Powyżej przestawione przykłady pytań oraz udzielanych nań odpowiedzi pozwalają dostrzec szereg działań OU, które - w ocenie nauczycieli-badaczy 
- wskazują na rozdźwięk między celami N/U formułowanymi w przedstawianym projekcie a oczekiwaniami i możliwościami OU.

$Z$ analizy danych wynika jasno, że OU nie są wdrożone do traktowania etapu poprzedzającego słuchanie jako ważnej części zadania rozumienia. Do takiego stwierdzenia upoważnia niska mobilizacja wiedzy, prowadząca do zbyt ogólnych lub unikowych odpowiedzi na pytania kwestionariusza. Co więcej, odpowiedzi te mają często formę narracyjną, np. kiedy OU ograniczają się do podania swojej opinii, nie podejmując jednocześnie działań oceniających w zakresie kompletności, spójności, czytelności, wiarygodności udzielanej wypowiedzi, czyli odmawiając niejako wpisania swoich argumentów w toczący się w mediach dialog społeczny. OU, w swoich komentarzach do wykonywanego $\mathrm{w}$ domu zadania niejednokrotnie oceniają pytania z kwestionariusza jako „łatwe”. Jednocześnie jednak, analiza pozwalała często dostrzec znaczącą różnicę między sposobem, w jaki temat jest negocjowany i kontekstualizowany w audycji a wstępnymi oczekiwaniami OU, które często zdawały się deprecjonować wymiar poznawczej nowości formułowanych w audycji tez, argumentów i opinii, a jednocześnie nie uwzględniały w swojej ocenie standardów myślenia krytycznego.

Ponadto, prawdopodobnie ze względu na skromne doświadczenia medialne w zakresie publicystyki społeczno-politycznej, stosowane przez OU strategie rozumienia i interpretacji w zbyt małym stopniu uwzględniają specyfikę gatunkową audycji. Na etapie przed słuchaniem, większość studentów oczekuje od rozmówców-ekspertów objaśniania danych obiektywnych, traktując tym samym dobór treści jako odpowiadający „dominującym” ujęciom społecznym. Tymczasem konfiguracja zaproszonych gości prowadzi niejednokrotnie do podnoszenia kwestii i argumentów nieobecnych lub mało eksponowanych w głównym nurcie debaty społecznej (por. pkt. 3.1.).

Jedną z poważniejszych trudności OU, wymagającą jednocześnie złożonej interwencji dydaktycznej jest niedostrzeganie przez słuchającego różnic kulturowych $\mathbf{w}$ sposobie rozwijania danej problematyki w polskim i francuskim dyskursie publicznym (np. rola i miejsce kobiet na rynku pracy). Skutkuje to nieudolnością w budowania spójnych i kompletnych interpretacji audycji na etapie poprzedzającym słuchanie, niekiedy dodatkowo wzmocnioną przez brak nawyku podejmowania samodzielnych działań dokumentujących (tj. działań ukierunkowanych na wyszukanie odpowiedniej informacji), jeśli wymaganie takie nie jest eksplicytnie ujęte w poleceniu.

Źródeł dostrzeżonego braku świadomości i niewystarczającego zaangażowania, a także przyczyn rozdźwięku między oczekiwaniami ON a realizacją zadania przez OU należy niewątpliwie upatrywać częściowo także w słabościach kwestionariusza, dlatego też działania wspierające rozwijanie kom- 
petencji słuchania u OU powinny uwzględnić krytyczną ocenę i przynajmniej częściową modyfikację niektórych z formułowanych w kwestionariuszu pytań tak, by skuteczniej przygotować OU do odbioru audycji.

\subsection{Konstruowanie kwestionariusza jako zadania wspierającego rozwój kompetencji rozumienia: postulowane zmiany $w$ formie i treści pytań na etapie przed słuchaniem}

Przeprowadzona analiza dobitnie pokazuje, że zadane przez ON pytania na etapie przed słuchaniem okazały się niewystarczające, by skutecznie przygotować OU do trudnego zadania interpretowania audycji radiowych. Najwyraźniej nie uwzględniały one potrzeb i reprezentacji OU, a co za tym idzie nie zawsze czytelnie prowadziły je ku postulowanym w projekcie celom kształcenia. Analiza zgromadzonych danych pozwoliła dostrzec trzy główne słabości w konstrukcji pytań:

- zbyt ogólnikowe i mało sproblematyzowane sformułowanie pytań, usprawiedliwiające po części zdawkową, nieuargumentowaną odpowiedź OU,

- brak eksplicytnych poleceń mających zachęcić do skutecznych działań uczeniowych (np. wskazanie przez ON konkretnych tekstów źródłowych, mogących ukierunkować uwagę i refleksję OU),

- brak konkretnej informacji nt. oczekiwań ON wobec odpowiedzi. ${ }^{3}$

Konfrontacja ustaleń teoretycznych odnoszących się do kompetencji OU na poziomie B2/C1 w odniesieniu do publicystycznych gatunków medialnych z odpowiedziami studentów, pozwala na określenie kilku zasad dotyczących formułowania pytań na etapie przed słuchaniem tak, by zawierały one bardziej precyzyjne wskazówki, a nawet sugerowały strategie wspomagające krytyczną interpretację audycji na etapie słuchania. Zamiast pytań ogólnych, pasujących do każdej audycji, ON powinna raczej stosować pytania, które wyraźnie wskazują na konkretne aspekty poruszanej problematyki (wymagają porównywania danych pochodzących z różnych źródeł, zachęcają do określenia wstępnych założeń danego problemu), zmuszają do jej problematyzowania i ekstrapolowania (zachęcają do wskazania zależności, uwarunkowań, zawierają pytania o prawomocność uogólnień), wymuszają większą aktywność informacyjną (wymagają uzupełniania zauważonych niedoborów na poziomie wiedzy, zwłaszcza dotyczącej Francji, wymagają analizy i syntezy informacji w oparciu o konkretne materiały/ strony internetowe), rozwijają

\footnotetext{
${ }^{3}$ Co prawda kwestionariusz podlegał każdorazowo omówieniu na forum grupy, ale najwyraźniej OU potrzebowały jeszcze ściślejszego prowadzenia.
} 
narzędzia myślenia krytycznego (zachęcają OU do krytycznej oceny swoich reprezentacji, a przede wszystkim do weryfikacji spójności i rzetelności swojego stanowiska wobec danego problemu, sugerują osadzenie swojego stanowiska w odpowiednim kontekście społecznym, etc.)

Poniżej nawiązano ponownie do wybranych przykładów pytań, tych samych, które były omawiane w pkt. 6.1. Po wskazaniu elementów w konstrukcji pytań, które mogą utrudniać realizację celów słuchania, jakie stawiane są w podejściu dyskursywnym (lewa kolumna tabelki), zaproponowano modyfikację ich formy i treści (prawa kolumna) zgodnie ze sformułowanymi wyżej zasadami.

\begin{tabular}{|c|c|}
\hline $\begin{array}{l}\text { anie sformułowane w kwestionariuszu } \\
\text { cena jego konstrukcji w świetle przyjętych } \\
\text { rojekcie celów N/U }\end{array}$ & $\begin{array}{l}\text { Propozycja modyfikacji pytania uwzględniają } \\
\text { założenia projektu }\end{array}$ \\
\hline $\begin{array}{l}\text { Przykład nr 1: Czy Francuzi bardziej ufają me- } \\
\text { diom niż Polacy? } \\
\text { Komentarz do formy i treści pytania: pytanie } \\
\text { może uzasadnić formułowanie ogólnikowej } \\
\text { odpowiedzi, nie zawiera bowiem wskazania } \\
\text { konieczności uzasadnienia opinii w oparciu } \\
\text { o rzetelną analizę }\end{array}$ & $\begin{array}{l}\text { mediami francuskimi i polskimi, wyjaśnij } \\
\text { różnice w świetle zmian historycznych doko } \\
\text { nych w ciągu ostatnich } 30 \text { lat (1) oraz biorąc } \\
\text { uwagę aktualne różnice społeczno-ekonomic } \\
\text { między obydwoma krajami (2). }\end{array}$ \\
\hline $\begin{array}{l}\text { ad 2: Jakie media cieszą się Twoim naj- } \\
\text { zym zaufaniem: radio, telewizja, prasa? } \\
\text { nij dlaczego. } \\
\text { ntarz do formy i treści pytania: brak naci- } \\
\text { argumentowanie, rozumiane jako działa- } \\
\text { oorządkowane podejmowane w określo- } \\
\text { elu poznawczym }\end{array}$ & $\begin{array}{l}\text { Modyfikacja pytania: wytłumacz, jak n } \\
\text { śnik/kanał informacji (audio, video, prasa dr } \\
\text { kowana, strony internetowe) mogą wpływać } \\
\text { sposób prezentacji informacji, ich odbiór i sk } \\
\text { teczność? }\end{array}$ \\
\hline $\begin{array}{l}\text { Przykład nr 3: Kogo spodziewasz się usłyszeć } \\
\text { w dyskusji na ten temat ? } \\
\text { Komentarz do formy i treści pytania: brak wska- } \\
\text { zania na konieczność uzasadnienia i wykazania } \\
\text { związku między składem zaproszonych gości } \\
\text { a kierunkiem rozmowy. }\end{array}$ & $\begin{array}{l}\text { Modyfikacja pytania: zaproponujcie dwa różr } \\
\text { zestawy zaproszonych gości/ekspertów d } \\
\text { dwóch wyraźnie określonych światopoglądon } \\
\text { dyskusji: jednej o charakterze feministyczny } \\
\text { i drugiej o charakterze konserwatywnym }\end{array}$ \\
\hline
\end{tabular}

\section{Podsumowanie}

Choć skromnych rozmiarów, przeprowadzone badanie posiada, w odczuciu autorek, sporą wartość poznawczą. Przede wszystkim pozwoliło ono na zweryfikowanie dość powszechnie przyjętych przekonań co do samodzielności uczeniowej studentów na poziomie zaawansowanym pokazując, że badana grupa na poziomie B2 potrzebuje prowadzenia ON, czasami nawet bardzo szczegółowego i konkretnego w rozwijaniu kompetencji rozumienia publicystycznych audycji radiowych. Ponadto badanie pozwoliło wskazać na ograni- 
czenia utartych sposobów planowania pracy na etapie przed słuchaniem, akcentując związek między rodzajem zadawanych pytań a podejmowanymi działaniami poznawczymi. Jednocześnie pozwoliło ono wykazać przydatność podejścia dyskursywnego między innymi jako źródła odpowiednich narzędzi (auto)dydaktycznych do diagnozy trudności i do proponowania strategii kształcenia dostosowanych do specyfiki rozumienia audycji radiowych. I wreszcie po raz kolejny potwierdziło ono istnienie ścisłego związku między rozwijaniem sprawności słuchania w języku obcym a kompetencjami ogólnymi (komunikacja, gatunki, wiedza społeczno-kulturowa).

\section{BIBLIOGRAFIA}

Berne, J. E. 2004. « Listening Comprehension Strategies: A Review of the Literature ». Foreign Language Annals 37 (4): 521-531.

Bronckart, J.-P. 1996. « L'acquisition des discours. Le point de vue de l'interactionnisme socio-discursif ». Le Français dans le Monde. Le discours : enjeux et perspectives. $n^{\circ}$ spécial: 55-64.

Charaudeau, P. 2005. "Sémantique de la langue, sémantique du discours » (w) Actes du colloque en hommage à Bernard Pottier. http://www.patrick-charaudeau.com /Semantique-de-la-langue-semantique.html. DW 14.052013.

Coste, D., North, B., Sheil, J. i Trim, J. 2003. Europejski system opisu kształcenia językowego: uczenie się, nauczanie, ocenianie. Warszawa: CODN.

Coubard, E. 2003. « Habitudes culturelles d'apprentissage en activité de compréhension orale ». Etudes de linguistique appliquée 132 (4): 445-455.

Dolz, J. i Schneuwly, B. 1998. Pour un enseignement de l'oral: initiation aux genres formels de l'oral. Paris: ESF Editeur.

Górecka, J., Wilczyńska, W. i Wojciechowska, B. (w druku). « Developing second language oral competence through an integrated discursive approach: The conceptual framework of the project and the pilot study results ". (w) Theoretical, empirical and pedagogic perspectives on teaching, learning and assessing speaking skills in a second language (red. M. Pawlak i E. Waniek-Klimczak).

Grzmil-Tylutki H. 2007. Gatunek w świetle francuskiej teorii dyskursu. Kraków: Universitas.

Kamber, A. i C. Skupien. 2008. « Les documents radiophoniques dans l'enseignement de la comprehension orale ». Mélanges CRAPEL 31: 173-189.

Leaver, B. L. i B. Shekhtman (ed.) 2002. Developing Professional-Level Language Proficiency. Cambridge: CUP.

Poussard, C. 2003. "Guider des stratégies de compréhension de l'oral en ALAO: le cas de l'inférence ". Apprentissage des langues et systèmes d'information et de communication. 6 (1): 143-150. <http://alsic.revues.org/2132?lang=en> DW 30.10.2012. 
Strzemeski, K. 2011. " Autonomizacja studentów poprzez ich samodzielną pracę z podcastami-plikami audio » (w) Autonomia w nauce języka obcego - uczeń a nauczyciel, (red. M. Pawlak). Poznań-Kalisz-Poznań: Wyd. UAM: 327-336.

Vandergrift, L. i Tafaghodtari, M. H. 2010. « Teaching L2 Learners How to Listen Does Make a Difference: An Empirical Study ». Language Learning 60 (2): 470-497.

Vandergrift, L., Goh C.C.M., Mareschal C. J. i Tafaghodtari, M. H. 2006. « The Metacognitive Awareness Listening Questionnaire: Development and Validation ». Language Learning 56 (3): 431-462.

Wilczyńska, W. i Wojciechowska, B. (w druku). " Świadomość gatunku dyskusja a rozumienie obcojęzycznych audycji radiowych ».

Wilczyńska, W. i Wojciechowska, B. (w druku). « Procédés interactifs de construction du sens dans l'émission Le téléphone sonne. Un modèle dans le développement des compétences orales élevées en L2 ॥. (w) Des organisations dynamiques de la langue orale (red. E. Richard i inni). Peter Lang.

Zaśko-Zielińska, M. 2002. Przez okno świadomości. Gatunki mowy w świadomości użytkowników języka. Wrocław: Wydawnictwo Uniwersytetu Wrocławskiego. 